\title{
Treatment of unclassified mycobacterial infection of the lungs
}

\author{
K. P. GOLD M A N ${ }^{1}$ \\ From Brompton Hospital, London, S.W.3
}

\begin{abstract}
In a review of 25 patients with pulmonary infection caused by unclassified mycobacteria the course of the disease is related to the method of treatment. Five patients were followed while not being treated; in four the disease progressed and in one it remained static, and in each case the organism persisted in the sputum. Sixteen patients were given combinations of streptomycin, isoniazid, and para-aminosalicylic acid for periods which varied between three months and two and a half years; there was bacteriological sputum conversion in six, although in each case the organism showed in vitro resistance to these drugs. Eleven patients were treated primarily with combinations of other anti-tuberculosis drugs for at least 12 consecutive weeks, after which the mycobacteria could no longer be cultured from the sputum in eight, in each case the organism showing in vitro sensitivity to the drugs. Ten patients received combined medical and surgical treatment, which was successful in eight and a failure in two, one of whom died post-operatively. A favourable response occurred most frequently when the disease was confined to one pulmonary radiographic zone and when less than 10 positive sputum cultures had been obtained. These results show that in this type of disease the response to chemotherapy is uncertain, in vitro drug sensitivity tests are of limited value, and combined medical and surgical treatment is usually effective.
\end{abstract}

There are patients with pulmonary disease closely resembling tuberculosis from whom acid-fast bacilli are isolated which differ from Mycobacterium tuberculosis or Mycobacterium bovis. These micro-organisms, which constitute a heterogeneous group, have been variously described as anonymous, atypical, or unclassified mycobacteria, although none of these names is wholly appropriate. The unclassified mycobacteria, as they will be called here, are distinguishable from tubercle bacilli and from each other in several ways, notably by colonial morphology, pigment production, and rate of growth. The most widely used system of classification is that proposed by Runyon (1959), who defined four main groups. Briefly, in group I (photochromogens) a yellow pigment is produced when colonies which have been cultured in darkness are exposed to light ; in group II (scotochromogens) pigment is produced during culture in darkness; in group III (nonphotochromogens) there is little or no pigment production whatever the conditions of culture; and in group IV there is rapid growth and no

1Present address: Royal Free Hospital, Gray's Inn Road, London, W.C.1 pigment production. Other characteristic features of these organisms are their production of catalase but not of niacin, absence of pathogenicity for guinea-pigs, and frequent in vitro resistance to para-aminosalicylic acid (P.A.S.), isoniazid, and streptomycin (Runyon, 1959 ; Marks and Trollope, 1960).

These bacteria are widely distributed in nature and their isolation from a patient is not necessarily of clinical significance. Thus casual strains may be inhaled and then expectorated or the sputum may become contaminated at the time of collection or at culture. However, in patients with chronic inflammatory disease of the lungs, from whom unclassified mycobacteria are isolated repeatedly, in the absence of other pathogens their aetiological significance must be presumed. In these cases the clinical, radiological, and pathological features may be indistinguishable from those of tuberculosis.

The role of these micro-organisms as human pathogens has been recognized only recently; experience of treatment is therefore limited and the most effective methods have yet to be determined. In this paper the course of the disease in 
25 patients is reviewed and an attempt is made to relate progress to the method of treatment. Although a controlled therapeutic trial would have been more valuable, the obstacle to this is the rarity of the condition and hence the difficulty in collecting a sufficient number of cases. This could be overcome only by a widespread cooperative study.

\section{CASE MATERIAL}

The records of the Tuberculosis Laboratory at Brompton Hospital were searched for the names of patients from whom unclassified mycobacteria had been cultured during the years 1957-66. Cases in which there was only one positive culture or in which tubercle bacilli had also been cultured were excluded because of doubt about the pathogenicity of the organism. Twenty-five patients fulfilled these conditions compared with 1,926 patients from whom tubercle bacilli had been cultured repeatedly, a ratio of $1: 77$.

The mycobacteria were identified by the appearance of colonies when cultured in light or darkness, by their rate of growth and the effect of temperature, and by tests for niacin production and for peroxidase and catalase activity. Classification was based on the system proposed by Runyon (1959).

In the majority of patients in this series, namely in 16 out of 25 , organisms from group I were isolated. In Britain this is the group most often pathogenic for man (Public Health Laboratory Service, 1962). Organisms from group III were cultured in six cases, from group II in two cases, and from group IV in one case (Table I).

T A B L E I

TYPES OF UNCLASSIFIED MYCOBACTERIA

\begin{tabular}{c|c}
\hline Runyon Group & No. of Patients \\
\hline II & 16 \\
II & 2 \\
III & 6 \\
IV & 1 \\
\hline
\end{tabular}

Streptomycin, isoniazid, and P.A.S. sensitivity tests were carried out in every case and, in addition, other anti-tuberculosis drugs were tested in many cases (Table II). The resistance ratio method was used: the minimal drug concentration to inhibit growth of the test organism is compared with the minimal concentration to inhibit the growth of a standard strain of $M y c o$. tuberculosis. A ratio of 4:1 was interpreted as
T A B L E I I

DRUG RESISTANCE (RESISTANCE RATIO $4: 1$ OR MORE)

\begin{tabular}{l|c|c}
\hline \multicolumn{1}{c|}{ Drug } & $\begin{array}{c}\text { No. of Strains } \\
\text { Tested }\end{array}$ & $\begin{array}{c}\text { No. of Strains } \\
\text { Resistant }\end{array}$ \\
\hline Isoniazid (I) & 25 & 25 \\
P.A.S. (P) & 25 & 24 \\
Streptomycin (S) & 25 & 21 \\
Pyrazinamide (Py) & 20 & 16 \\
Thiacetazone (Th) & 20 & 10 \\
Ethionamide (Et) & 20 & 3 \\
Viomycin (Vi) & 21 & 6 \\
Cycloserine (Cy) & 21 & 2 \\
Ethambutol (E) & 5 & 3 \\
Capreomycin (Cap) & 4 & 4 \\
\hline
\end{tabular}

partial resistance and of $8: 1$ as resistance. There was partial or full resistance to isoniazid in all strains, to P.A.S. in all except one strain, and to streptomycin in all except four. The majority of strains were also resistant to pyrazinamide, namely 16 out of the 20 tested. The drugs to which the highest proportion of strains were sensitive were cycloserine, ethionamide, and viomycin. In only one case did the pattern of drug resistance change from that found initially, namely in a patient infected with group III organisms which were initially sensitive to cycloserine but which became resistant to it after treatment.

There were 21 men and four women in the series and their ages ranged from 21 to 78 years. The initial chest radiographs were reviewed and the extent of the disease was recorded according to the number of zones showing abnormal shadows, each lung field being divided into upper, middle, and lower zones on the postero-anterior view. Only one zone was involved in 12 patients, two zones in eight, and three zones or more in five. A cavity was visible in every case except one, although tomography was often required for its demonstration.

PROGRESS AND TREATMENT The course of the disease in these 25 patients has been followed for periods of up to nine years, the length of followup varying according to the date of the first attendance at hospital. From the time of the first positive sputum culture the follow-up was for at least two years (or until death, if this occurred in less than two years) in 20 patients, for at least three years in 13, and for at least five years in eight.

For assessment of the effects of treatment two criteria of progress have been adopted, namely disappearance of the mycobacteria from the sputum and a change in the radiographic appearance of the lungs. Other criteria which might have been employed, such as a change in weight, sputum volume, temperature, and erythrocyte 
sedimentation rate, were considered to be insufficiently critical.

The effect of treatment on the course of a disease cannot accurately be assessed without a detailed knowledge of its natural history. Five patients were followed while not being treated. Two who were infected with photochromogens did not start treatment until they had been observed for 21 months (case 8) and three years (case 6) respectively. The former patient became more ill during this period, the sputum persistently contained the organisms, and the extent of radiographic shadowing increased; the latter patient showed no clinical or radiological change, although his sputum was consistently shown to contain the organism. A third patient, who was infected with a group II organism (case 14), was not treated for seven months, during which time there was clinical and radiological worsening and the organisms persisted in the sputum. In two other patients, after ineffective initial chemotherapy, there was an interval of over a year without any treatment. In this time there was radiological evidence of extension of the disease (cases 4 and 10). Thus, of the five patients who were observed while not receiving treatment, in four the disease showed signs of extension and in one it remained

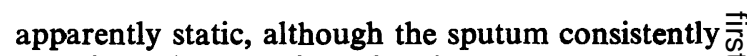
contained the organisms for three years.

Chemotherapy with various combinations of $\frac{C}{0}$ streptomycin, isoniazid, and P.A.S. was given to 20 patients (Table III). In four, the drugs were $\overparen{\mathbb{D}}$ stopped in less than two months, a period too short for assessment of any likely therapeutic ${ }^{\text {कs }}$ effect. The remaining 16 patients were given this $\vec{O}$ treatment for periods varying from three months $\overrightarrow{-}$ to two and a half years (average duration $13 \frac{1}{2} \vec{\omega}$ months). In only six of these patients did the $\Rightarrow$ organisms disappear from the sputum (cases 5,11 , $x$ $14,18,20$, and 25 ), and one of them relapsed after chemotherapy had been given for two years. In $-\overrightarrow{0}$ the other 10 patients, organisms continued to be cultured from the sputum despite treatment, 으 although in two there was some radiological im-provement. One patient showed evidence of extension of the disease after two years of treatment (case 22). Thus, measured in this way, the response to the three above-mentioned drugs was poor.There was no correlation between the clinical 8 results and the results of in vitro sensitivity tests,, for in each of the six patients who apparently responded to streptomycin, isoniazid, and P.A.S.S the strain of mycobacteria was reported as resistant to these drugs.

T A B L E I I I

RESULTS OF MEDICAL TREATMENT

\begin{tabular}{|c|c|c|c|c|c|c|c|c|c|c|c|}
\hline \multirow[b]{2}{*}{ No. } & \multirow[b]{2}{*}{ Age } & \multirow[b]{2}{*}{ Sex } & \multicolumn{2}{|c|}{$\begin{array}{c}\text { Chest } \\
\text { Radiograph }\end{array}$} & \multicolumn{2}{|c|}{ Bacteriology } & \multirow[b]{2}{*}{ Chemotherapy ${ }^{1}$} & \multicolumn{4}{|c|}{ After Treatment } \\
\hline & & & $\begin{array}{l}\text { No. of } \\
\text { Zones }\end{array}$ & Cavity & $\begin{array}{c}\text { Runyon } \\
\text { Group }\end{array}$ & $\begin{array}{l}\text { No. of } \\
\text { Cultures }\end{array}$ & & $\begin{array}{l}\text { Sputum } \\
\text { Culture }\end{array}$ & $\begin{array}{l}\text { Radio- } \\
\text { graphic } \\
\text { Change }\end{array}$ & $\begin{array}{l}\text { Follow- } \\
\text { up }\end{array}$ & Surviva \\
\hline 1 & 39 & $\mathbf{F}$ & 1 & Yes & I & 2 & S, P, I 8 wks & - & Nil & 2 yrs & Alive \\
\hline $\mathbf{2}$ & $\begin{array}{l}59 \\
32\end{array}$ & $\begin{array}{l}\mathbf{M} \\
\mathbf{M}\end{array}$ & 2 & $\begin{array}{l}\text { Yes } \\
\text { Yes }\end{array}$ & I & $\stackrel{7}{10+}$ & $\begin{array}{l}\text { Et, Cy } 15 \text { mths } \\
\text { P, I } 7 \text { mths }\end{array}$ & $\bar{t}$ & $\begin{array}{l}\text { Better } \\
\text { Better }\end{array}$ & $\begin{array}{l}5 \% \text { yrs } \\
2 \text { yrs }\end{array}$ & $\begin{array}{l}\text { Alive } \\
\text { Alive }\end{array}$ \\
\hline 4 & 64 & $\mathbf{M}$ & 1 & Yes & $\mathbf{I}$ & $10+$ & P, I 21 mths & $\overline{+}$ & Nil & $4 \frac{1}{2}$ yrs & Dead \\
\hline 5 & 36 & $\mathbf{M}$ & 1 & Yes & $\mathbf{I}$ & 5 & S, P, I 11 wks & \pm & Better & $3 \frac{1}{2}$ yrs & Alive \\
\hline 6 & 49 & $\mathbf{M}$ & 1 & Yes & $\mathbf{I}$ & 9 & Nil 3 years & \pm & Nii & 5 mths & Alive \\
\hline 7 & 50 & $\mathbf{M}$ & 1 & Yes & I & 4 & $\begin{array}{l}\text { Cy, Py } 11 \text { wks } \\
\text { Cy, Et } 6 \text { mths }\end{array}$ & $\bar{z}$ & $\begin{array}{l}\text { Better } \\
\text { Nil }\end{array}$ & $2 \frac{1}{2}$ yrs & Alive \\
\hline $\begin{array}{l}8 \\
9\end{array}$ & $\begin{array}{l}64 \\
27\end{array}$ & $\begin{array}{l}\mathbf{M} \\
\mathbf{M}\end{array}$ & $\begin{array}{l}2 \\
2\end{array}$ & $\begin{array}{l}\text { Yes } \\
\text { Yes }\end{array}$ & $\begin{array}{l}\mathbf{I} \\
\mathbf{I}\end{array}$ & $\begin{array}{l}10+ \\
10+\end{array}$ & $\begin{array}{l}\text { Nil } 21 \text { mths } \\
\text { S, P, I } 4 \text { mths } \\
\text { P, I } 12 \text { mths }\end{array}$ & $\begin{array}{l}+ \\
+ \\
+\end{array}$ & $\begin{array}{l}\text { Worse } \\
\text { Nil } \\
\text { Nil }\end{array}$ & $\begin{array}{l}1 \neq \mathrm{yrs} \\
.7 \frac{3}{\mathrm{yrs}}\end{array}$ & $\begin{array}{l}\text { Dead } \\
\text { Dead }\end{array}$ \\
\hline 10 & 50 & $\mathbf{F}$ & 3 & Yes & III & $10+$ & $\begin{array}{l}\text { Cy, Et, Vi intermittent } \\
\text { S, P, I } 3 \text { mths } \\
\text { Nil \& m ms } \\
\text { P, Py } 6 \text { mths }\end{array}$ & $\begin{array}{l}+ \\
+ \\
+\end{array}$ & $\begin{array}{l}\text { Nil } \\
\text { Nil } \\
\text { Worse } \\
\text { Nil }\end{array}$ & $\begin{array}{l}2 \mathrm{yrs} \\
11 \mathrm{mths}\end{array}$ & Dead \\
\hline 11 & 60 & $\mathbf{M}$ & 1 & Yes & III & 6 & $\begin{array}{l}\text { Nil } 16 \text { mths } \\
\text { S, P, I } 10 \text { mths }\end{array}$ & \pm & $\begin{array}{l}\text { Worse } \\
\text { Better }\end{array}$ & 1 th yrs & Alive \\
\hline 12 & $\begin{array}{l}60 \\
39\end{array}$ & $\mathbf{M}$ & $\begin{array}{l}3 \\
1\end{array}$ & $\begin{array}{l}\text { Yes } \\
\text { No }\end{array}$ & . III & $\begin{array}{l}10 \\
10\end{array}$ & $\begin{array}{l}\text { S, Et } 8 \text { mths } \\
\text { S, P. I } 9 \text { wks } \\
\text { P, I } 6 \text { mths }\end{array}$ & $\overline{+}$ & $\begin{array}{l}\text { Bil } \\
\text { Better } \\
\text { Better } \\
\text { Nil }\end{array}$ & $\begin{array}{l}10 \mathrm{mths} \\
1 \mathrm{yr}\end{array}$ & $\begin{array}{l}\text { Alive } \\
\text { Alive }\end{array}$ \\
\hline 14. & 78 & $\mathbf{M}$ & 2 & Yes & II & 3 & $\begin{array}{l}\text { Py, Et } 5 \mathrm{mths} \\
\text { Nii } 7 \mathrm{mths} \\
\text { miths }\end{array}$ & + & $\begin{array}{l}\text { Nil } \\
\text { Worse }\end{array}$ & $\begin{array}{l}1 \mathrm{mth} \\
2 \mathrm{yrs}\end{array}$ & Dead \\
\hline 15 & 38 & $\mathbf{F}$ & 3 & Yes & IV & $10+$ & $\begin{array}{l}\text { Cy, Et, Py } 7 \mathrm{mths} \\
\text { Cy, Py } 6 \text { mths }\end{array}$ & $\stackrel{+}{+}$ & $\begin{array}{l}\text { Nil } \\
\text { Nil }\end{array}$ & $21 \mathrm{yrs}$ & Dead \\
\hline
\end{tabular}

${ }^{1}$ For explanation of abbreviations of drugs see Table II. 
Many patients were treated with other antituberculosis drugs, namely pyrazinamide, cycloserine, ethionamide, viomycin, thiosemicarbazone, and capreomycin. They were prescribed in combinations largely determined by the in vitro sensitivity pattern. Of 11 patients who received this type of chemotherapy for at least 12 consecutive weeks, the organisms disappeared from the sputum after treatment in five (cases $2,3,6,7$, and 10). In three others the sputum was already bacteriologically negative before these drugs were started (cases 1, 5, and 11), so their effect was not easily determined, but because radiological improvement followed treatment in two it was thought to have been of value. This chemotherapy was of no benefit to three patients who had advanced disease (cases 9, 13, and 15); one was infected with organisms which showed in vitro resistance to all the drugs tested. Thus the laboratory tests provided an approximate guide as to which patients would respond to this type of chemotherapy, for of the 10 whose drugs were selected strictly according to the in vitro sensitivity tests, seven showed an apparent response to treatment. There was bacteriological sputum conversion also in one patient treated with isoniazid, ethionamide, and viomycin, the organisms showing in vitro sensitivity to the latter two drugs (see case 1), and in another treated with streptomycin and ethionamide, the organism showing in vitro sensitivity to both drugs (case 12).

Surgical treatment was performed on 10 patients, namely four segmental resections, two lobectomies, three thoracoplasties, and one plombage (Table IV). A favourable result was achieved in eight of these patients-sputum conversion immediately following operation and maintained throughout the follow-up period, which varied between one and eight years. In five of these eight cases a pre-operative course of chemotherapy had been ineffective. Chemotherapy was given to all except one patient and may have contributed to the good results. There were two surgical failures. One patient died 10 days after segmental resection from a combination of pulmonary haemorrhage and bronchopleural fistula (case 17), this being the only serious post-operative complication. In the other patient, who had advanced bilateral disease which had not responded to two years of chemotherapy, a plombage operation was ineffective (case 24).

The results of medical and surgical treatment have been analysed according to the extent of pulmonary disease. Of the patients whose chest radiographs showed disease in only one pulmonary zone the outcome was successful in nine out of 11, whereas of those with more than one zone affected only seven out of 13 did well (excluding

T A B L E IV

RESULTS OF COMBINED MEDICAL AND SURGICAL TREATMENT

\begin{tabular}{|c|c|c|c|c|c|c|c|c|c|c|}
\hline \multirow[b]{2}{*}{ No. } & \multirow[b]{2}{*}{ Age } & \multirow[b]{2}{*}{ Sex } & \multicolumn{2}{|c|}{ Chest Radiograph } & \multicolumn{2}{|c|}{ Bacteriology } & \multirow{2}{*}{ Treatment $^{1}$} & \multicolumn{3}{|c|}{ After Treatment } \\
\hline & & & $\begin{array}{l}\text { No. of } \\
\text { Zones }\end{array}$ & Cavity & $\begin{array}{c}\text { Runyon } \\
\text { Group }\end{array}$ & $\begin{array}{l}\text { No. of } \\
\text { Cultures }\end{array}$ & & $\begin{array}{l}\text { Sputum } \\
\text { Culture }\end{array}$ & Follow-up & Survival \\
\hline 16 & 38 & $\mathbf{M}$ & 2 & Yes & I & $10+$ & $\begin{array}{l}\text { S, P, I } 3 \text { mths } \\
\text { Lobectomy } \\
\text { Cy, Et, Cap } 6 \text { mths }\end{array}$ & $\begin{array}{l} \pm \\
-\end{array}$ & $1 \frac{1}{2}$ yrs & Alive \\
\hline 17 & 45 & $\mathbf{M}$ & 1 & Yes & I & $10+$ & $\begin{array}{l}\text { S, P, I } 5 \text { wks } \\
\text { I, Cy, Et } 8 \text { wks } \\
\text { Segmental resection }\end{array}$ & + & 10 days & Dead \\
\hline 18 & 47 & $\mathbf{M}$ & 1 & Yes & I & 5 & $\begin{array}{l}\text { S, P, I } 5 \text { mths } \\
\text { Segmental resection } \\
\text { P, I 1 mth }\end{array}$ & $\overline{-}$ & 3 yrs & Alive \\
\hline 19 & 21 & $\mathbf{M}$ & 1 & Yes & I & $10+$ & $\begin{array}{l}\text { S, P, I } 2 \text { mths } \\
\text { Segmental resection } \\
\text { Cy, Et } 10 \text { mths }\end{array}$ & $\stackrel{+}{-}$ & $4 \frac{1}{4}$ yrs & Alive \\
\hline 20 & 59 & $\mathbf{M}$ & 1 & Yes & I & 2 & $\begin{array}{l}\text { S, I } 9 \text { mths } \\
\text { Segmental resection } \\
\text { P, I } 5 \text { mths }\end{array}$ & $\begin{array}{l}- \\
-\end{array}$ & $\begin{array}{l}6 \text { yrs } \\
11 \mathrm{mths}\end{array}$ & Dead \\
\hline 21 & 55 & $\mathbf{M}$ & 2 & Yes & I & $10+$ & $\begin{array}{l}\text { S, P, I } 20 \text { mths } \\
\text { Thoracoplasty } \\
\text { Cy, Et } 8 \text { months }\end{array}$ & $\begin{array}{l}+ \\
-\end{array}$ & $6 \frac{1}{2}$ yrs & Alive \\
\hline 22 & 43 & $\mathbf{F}$ & 3 & Yes & I & $10+$ & $\begin{array}{l}\text { P, I } 2 \text { yrs } \\
\text { Thoracoplasty } \\
\text { P, I } 6 \text { mths }\end{array}$ & $\begin{array}{l}+ \\
-\end{array}$ & $\begin{array}{l}9 \text { yrs } \\
2 \text { mths }\end{array}$ & Alive \\
\hline 23 & 52 & $\mathbf{M}$ & 1 & Yes & $\begin{array}{l}\text { II } \\
\text { III }\end{array}$ & $\begin{array}{c}8 \\
10+\end{array}$ & $\begin{array}{l}\text { P, I } 8 \text { mths } \\
\text { Lobectomy } \\
\text { Et, Py } 14 \text { mths } \\
\text { S, P, I or P, I } 2 \frac{1}{2} \text { yrs }\end{array}$ & $\begin{array}{l}+ \\
\frac{-}{+}\end{array}$ & $\begin{array}{l}2 \mathrm{yrs} \\
2 \mathrm{mths}\end{array}$ & Alive \\
\hline & 52 & $1 \mathrm{n}$ & 4 & IES & & Not & $\begin{array}{l}\text { Plombage } \\
\text { Vi, Cy, Et } 6 \text { mths }\end{array}$ & + & $5 \frac{1}{2}$ yrs & Dead \\
\hline 25 & 28 & $\mathbf{M}$ & 2 & Yes & III & 7 & $\begin{array}{l}\text { S, I, } 5 \text { mths } \\
\text { P, I } 21 \text { mths } \\
\text { Thoracoplasty }\end{array}$ & $\frac{1}{+}$ & & Alive \\
\hline
\end{tabular}


the patient who died after operation). There is also a correlation with the number of positive sputum cultures. Thus the organisms disappeared from the sputum after treatment in 10 out of 11 patients who produced less than 10 pre-treatment positive cultures and in only six out of 13 patients who produced 10 or more pre-treatment positive cultures.

Of the 25 patients in this series who were followed until 1 November 1966, nine had died. One death followed a thoracotomy and two deaths were from causes unrelated to the main pulmonary disease, namely lobar pneumonia and a road accident. In the remaining six patients the mycobacterial infection was thought to have been only a contributory cause of death; five had either advanced chronic bronchitis or emphysema with terminal respiratory failure and the sixth had widespread pulmonary fibrosis. These patients died between 21 months and seven years after the time of diagnosis.

\section{DISCUSSION}

Unclassified mycobacteria are thought to be pathogenic when they are repeatedly isolated from a patient with a chronic inflammatory lesion of the lung for which no other likely cause has been found. The different types of organism all produce clinical, radiological, and pathological features which closely resemble those of classical pulmonary tuberculosis. The most common symptom is a productive cough, often with haemoptysis, but systemic upset such as fever or weight loss is unusual. Cavitation is almost always visible on the radiograph, with surrounding infiltration or fibrosis present in varying degrees. The pathology is indistinguishable from that of tuberculosis, but, although the lymph glands may be involved, haematogenous dissemination rarely, if ever, occurs. If left untreated in some patients the disease apparently remains quiescent while in others it slowly progresses, there being local extension similar to that seen in some cases of indolent tuberculosis.

The principal therapeutic problem arises because most strains of unclassified myobacteria show in vitro resistance to streptomycin, isoniazid, and P.A.S. A favourable response to these drugs, therefore, would not be expected, although the published evidence on this point is conflicting. Thus Christianson and Dewlett (1960) reported that in 22 out of 24 patients infected with photochromogens the organism disappeared from the sputum after this method of treatment (two subsequently relapsed), and Pfuetze, Nuchprayoon, Berg, and Pamintuan (1966) treated 21 patients in this way and at the end of one year all had negative sputum. Other authors have reported less good results. In three different studies on the effect of this type of chemotherapy on patients infected with photochromogens, bacteriological sputum conversion was achieved in 22 out of 44 cases (Kamat, Rossiter, and Gilson, 1961), in seven out of 15 (Zvetina, 1965), and in four out of 12 (Kettel, 1965). Much less information has been published about the response of patients infected with group III organisms. In the only large series to be reported, $22 \%$ of 180 patients became 'sputum-negative' after treatment with streptomycin, isoniazid, and P.A.S. (Corpe and Liang, 1960). In the present series of 16 patients treated in this way, nine of whom had photochromogenic infections, the sputum became negative in six and there was one relapse.

It is difficult to explain why some patients $\vec{\bullet}$ improve when treated with streptomycin, isonia- $\infty$ zid, and P.A.S. although the organisms which have been cultured from their sputum show in vitro resistance to these drugs. Either the sensitivity tests are inadequate or the improvement is related to factors other than the chemotherapy. The answer to this question must await the results of a controlled clinical trial; meanwhile the author's policy is to treat these patients with drugs to which their organisms show in vitro sensitivity.

The effectiveness of drugs other than streptomycin, isoniazid, and P.A.S. has yet to be determined and no large trials have been reported. In the present series, out of 10 patients who were given various combinations of these drugs for at least 12 weeks, selected according to in vitro sensitivity tests, there was an apparent response in seven. Treatment for 12 months or longer might have resulted in a higher success rate, but the duration of therapy was frequently limited by drug toxicity. Our general impression is of a limited chance of success whatever the type of chemotherapy used, although it has been reported that the response to treatment is better with organisms from group I than from group III (Jenkins, 1959 ; Corpe, Runyon, and Lester, 1963 ; Phillips and Larkin, 1964). Clinical infection with organisms from group IV presents the biggest problem of treatment, for they are commonly resistant both in vivo and in vitro to all the antituberculosis drugs (see case 15).

Because of the uncertain outcome of medical treatment many patients are treated surgically, 
most often with success. Thus Jenkins, Bahar, and Chofnas (1960) operated on 61 patients infected with photochromogens and two years later $95 \%$ had negative sputum. Lewis, Lasché, Armstrong, and Dunbar (1960) performed 37 resections and one plombage on 38 patients infected with group III organisms and $87 \%$ were rendered 'sputumnegative'. Corpe and Liang (1960) operated on 25 patients, mainly with group III infections, and all who survived operation were rendered 'sputum-negative'. Law (1964) performed 101 operations on 98 patients and claimed a $94 \%$ success rate. Corpe (1964) operated on 330 patients with group III infections and concluded that surgical treatment had a $75 \%$ chance of success. In our patients a satisfactory surgical result was achieved in eight out of 10 cases. The majority of patients treated surgically are also given chemotherapy, which may contribute to the result.

The reported incidence of post-operative complications is fairly high, particularly bronchopleural fistulae. Harrison, Reimann, Long, Lester, and Adams (1959) performed 14 resections which resulted in three bronchopleural fistulae and two other major complications. Corpe and Liang (1960) reported three fistulae and two haemorrhages after 38 operations, and Law (1964) had eight major complications after 101 operations. In the present series haemorrhage and bronchopleural fistula proved fatal in one patient treated surgically. The relatively high complication rate might arise because of the difficulty in finding an effective combination of drugs for operative cover. However, acute dissemination of the disease is not encountered in the post-operative period.

The overall success rate of combined medical and surgical treatment appears to be greater than that of medical treatment alone. This may partly result from a bias in case selection, for most patients treated surgically have less extensive disease. However, if allowance is made for this factor it still seems that the combined method of treatment is more effective. Therefore it should be considered whenever organisms persist in the sputum after several months of chemotherapy, provided the patient is fit enough and the disease is sufficiently localized. An initial course of chemotherapy is justified, because in a proportion of patients treated in this way the mycobacteria disappeared from the sputum and surgery is unnecessary.

I should like to thank Dr. W. D. W. Brooks and Dr. R. Riddell for their helpful criticism of the manuscript. Thanks are also due to members of the Tuberculosis Laboratory at Brompton Hospital for their co-operation.

\section{REFERENCES}

Christianson, L. C., and Dewlett, H. J. (1960). Pulmonary disease associated with anonymous mycob acteria in adults in a tuberculosis hospital. In The Anonymous Mycobacteria in Human Disease. Ed. Chapman, J. S., p. 70. Thomas, Springfield, Illinois.

Corpe, R. F. (1964). Clinical aspects, medical and surgical, in the management of Battey-type pulmonary disease. Dis. Chest, 45, 380 .

- and Liang, J. (1960). Surgical resection in pulmonary tuberculosis due to atypical mycobacterium tuberculosis. $J$. thorac. cardiovasc. Surg., 40, 93.

- Runyon, E. H., and Lester, W. (1963). Status of disease due to unclassified mycobacteria. Amer. Rev. resp. Dis., 87, 459.

Harrison, R. W., Reimann, A. F., Long, E. T., Lester, W., and Adams, W. E. (1959). Adverse surgical experience in the treatment of pulmonary disease caused by atypical acid-fast bacilli. $J$. thorac. cardiovasc. Surg., 38, 481.

Jenkins, D. E. (1959). Recent clinical studies in the U.S. on atypical acid-fast bacilli. Bull. Un. int. Tuberc., 29, 295.

- Bahar, D., and Chofnas, I. (1960). Pulmonary disease due to atypical mycobacteria: current concepts. Trans. 19th Conf. on Chemotherapy of Tuberculosis, V.A.-Armed Forces, p. 224.

Kamat, S. R., Rossiter, C. E., and Gilson, J. C. (1961). A retrospective clinical study of pulmonary disease due to "anonymous mycobacteria" in Wales. Thorax, 16, 297.

Kettel, L. J. (1965). Clinical course of 12 patients with pulmonary infection with $M$. Kansasii. Trans. 24th Res. Conf. in Pulmonary Diseases, V.A.-Armed Forces, p. 78.

Law, S. W. (1964). Surgical treatment of atypical mycobacterial disease: a survey of experience in Veterans Administration hospitals. Trans. 23rd Res. Conf. in Pulmonary Diseases, V.A.Armed Forces, p. 37

Lewis, A. G., Lasché, E. M., Armstrong, A. L., and Dunbar, F. P. (1960). A clinical study of the chronic lung disease due to nonphotochromogenic acid-fast bacilli. Ann. intern. Med., 53, 273.

Marks, J., and Troll 'pe, D. R. (1960). A study of the 'anonymous' mycobacteria. Tubercle (Lond.), 41, 133.

Pfuetze, K. M., Nuchprayoon, C. V., Rerg, G. S., and Pamintuan, R. (1966). Present status of open negative cavities due to photochromogenic mycobacteria among cooperative patients. Amer. Rev. resp. Dis., 94, 467.

Phillips, S., and Larkin, J. C. (1964). Atypical pulmonary tuberculosis caused by unclassified mycobacteria. Ann. intern. Med., 60, 401 .

Public Health Laboratory Service (1962). Anonymous mycobacteria in England and Wales. I. Prevalence and methods of identification. Tubercle (Lond.), 43, 432.

Runyon, E. H. (1959). Anonymous mycobacteria in pulmonary disease. Med. Clin. N. Amer., 43, 273.

Zvetina, J. R. (1965). Clinical course of 15 patients with pulmonary infection with M. Kansasii. Trans. 24th Res. Conf. in Pulmonary Diseases, V.A.-Armed Forces, p. 74. 